\title{
Frequency and Severity of Trunk Decay in Street Tree Maples in Four New York Cities
}

\author{
Christopher J. Luley, David J. Nowak, and Eric J. Greenfield
}

\begin{abstract}
A proportional random selection of street tree Norway, silver, and sugar maples, and other species among four diameter classes were surveyed in the U.S.' New York cities of Albany, Buffalo, Rochester, and Syracuse for decay incidence and severity. Decay was determined by drilling sampled trees with a Resistograph and calculating the ratio of sound wood to radius. Overall, $58.3 \%$ of the sampled trees had some amount of decay and incidence was highest in sugar maples and in the largest size class trees. However, decay incidence was high (53.2\%) even in the smallest diameter tree size class (30.5-45.7cm (12-18 in). Decay severity was greatest in silver maple and in the largest diameter trees, although only $3.2 \%$ of the trees sampled had serious decay. The study shows that decay is common in street trees but is seldom severe. It also suggests that decay becomes established early in the life of street trees but is most severe in larger diameter trees and in trees that compartmentalize decay poorly such as silver maple. The frequency and severity of decay in the cities studied indicates that they need to continue to identify and manage trees with decay.

Key Words. Decay; Resistograph; street trees; maples; hazard trees; carbon loss
\end{abstract}

Little is known about the frequency and severity of decay in urban trees. Tate (1984; Tate 1986) quantified the incidence of decay in trees using an increment borer, and found that it ranged from $13 \%$ in street trees in New Jersey to $16 \%$ in Central Park, New York City. The development of a number of commercially available decay detecting tools, such as the Resistograph, Picus tomography, tree radar, and others (Nicolotti and Miglietta 1998; Gilbert and Smiley 2004) now allow a more extensive investigation of both the incidence and severity of decay in trees using minimally invasive testing methods.

In New York State, maples species frequently dominate the street tree population, and it is common for Norway (Acer platanoides), silver (A. saccharinum), sugar (A. saccharum), red (A. rubrum), and other maples to comprise over $50 \%$ of the population in both small communities and larger cities (Manion 1981a; Jaenson et al. 1992; Sisinni et al. 1995). In some cases, Norway maple alone may comprise over $50 \%$ of the planted street trees (Manion 1981a). Many of these maples were replacements for the American elms (Ulmus americana) that were lost as a result of the Dutch elm disease epidemic that started in the 1930's (Nowak and Rowntree 1990). Therefore, a significant portion of this maple population is mature; and the health, structural stability, and carbon storage as affected by wood decay, is in question. Furthermore, the upstate New York maple population is threatened by the presence and potential northern and western spread of the Asian Longhorned Beetle currently known to infest parts of New York City, Long Island, Massachusetts and New Jersey. This insect has potential to seriously impact the health and structural stability of maples and other species in New York.

This research was initiated to determine the incidence and severity of wood decay in street tree maples and other species in Albany, Buffalo, Rochester, and Syracuse, New York. It used a Resistograph, visual evaluation, and sounding evaluation with a mallet to estimate decay frequency and amounts. The Resistograph allows for rapid decay testing and has been used in a variety of testing environments including decay in trees (Costello and Quarles 1999; Bethge et al. 1996; Mattheck et al. 1997), wood in service (Brashaw et al. 2005), and assessment of wood density of genetic crosses (Isik and Li 2003). This paper reveals the first set of results from this research on the frequency of decay and severity of decay in street tree trunks among four cities, four tree species classes, and four diameter classes.

\section{MATERIALS AND METHODS}

\section{Sample Selection}

The sample for the study was taken from street tree inventory data of trees greater than $30.5 \mathrm{~cm}$ (12 in) in diameter provided by the cities of Albany, Buffalo, Rochester, and Syracuse, New York. The inventories in each city were complete except for Albany where outlying portions of the city had yet to be inventoried. The initial sample was comprised of a random selection of 480 trees per city, and included thirty Norway, silver, and sugar maple, and "other" species (random selection from all other species present in the city) in each of four diameter-at-breast-height $(\mathrm{DBH}$; diameter at $1.37 \mathrm{~m}(4.5 \mathrm{ft})$ classes. The random selection of trees was made in each selection class (diameter and species) by pooling all the trees from the inventory for each city individually and then selecting from that pool of species. Other species included in the sample, starting with the most frequent were, Tilia cordata, Gleditsia triacanthos, Platanus $x$ acerifolia, Fraxinus pennsylvanica, Acer rubrum, Aeculus hippocastanum, Quercus rubra, F. americana, Ulmus spp., Q. palustris, T. americana, Zelkova serrata, P. occidentalis, Acer negundo, Celtis occidentalis, and Liquidambar styraciflua, and 39 other species that comprised the remaining $15 \%$ of the sample. The four DBH classes were $30.5-45.7 \mathrm{~cm}(12-18$ in), $45.7-61 \mathrm{~cm}$ (18-24 in), 61-76.2 cm (24-30 in), and greater than $76.2 \mathrm{~cm}$ (30 in). Field data were collected from June to October, 2007. 


\section{Decay Testing Procedures}

All trees were tested for decay by drilling three times at $\mathrm{DBH}$ using the Resistograph F400. The Resistograph uses a $38 \mathrm{~cm}$ (15 in), $3 \mathrm{~mm}$ (0.12 in) diameter drill bit to record mechanical resistance to the bit on chart paper (Mattheck et al. 1997). The largest diameter class of trees tested was greater than $76.2 \mathrm{~cm}$ (30 in) and the drill bit would not have sampled the wood deeper in the stem beyond the $38 \mathrm{~cm}$ (15 in) it extends. Therefore, the presence of decay in the largest diameter class would be underestimated using this drilling method. By detecting decay as a decrease in resistance to the drill bit, the tool allows a measurement of the thickness of outer shell of wood showing high resistance to the bit (interpreted in this study as non-decayed wood or sound wood) at the drill site (Mattheck et al. 1997). A drop in resistance for more than $13 \mathrm{~mm}(0.5 \mathrm{inch})$ was interpreted as the indication of decay. In cases where the bark and cambium were dead and sapwood was decayed but wood deeper in the stem was solid, or sapwood rot (Luley 2006) was present, the thickness of the outer shell was recorded as zero. After removing the thickness of the bark, the thickness of the outer shell of non-decayed wood was recorded after the evaluation of each drill path.

Decay incidence and severity were also evaluated at each tree using indicators of decay (Shigo 1966; Manion 1981b; Young 1984; Mattheck and Breleor 1994; Luley 2006). Each decay indicator was evaluated visually and then tested by sounding around the circumference of the tree at the site of the indicator with a 170 g (6 oz) Sears Craftsman hammer (model number 38292) with a hardened plastic head. Visual assessment and sounding were used to make a field judgment of a second test location for decay. A series of three Resistograph F400 drillings around the circumference of the tree was made at the height of the decay indicator that was assessed to have the greatest amount of decay based on visual assessment and sounding. If no decay indicators were present, the tree was drilled only three times at breast height. Decay testing was performed only on the main trunk above the roots to a height of $3.1 \mathrm{~m}(10 \mathrm{ft})$. Scaffold branches were not tested for decay if the tree forked below $3.1 \mathrm{~m}$. However, if decay indicators were present on buttress roots adjacent to the trunk, the indicator was tested for decay at the trunk above the indicator.

\section{Statistical Analysis}

Sampled trees were categorized into presence or absence of decay. Decay was indicated if a Resistograph drilling at either DBH or at an indicator produced a ratio of sound wood distance to stem radius of less than 1.00 . Sampled trees were also placed into one of five categories based on the amount of decay averaged from the three Resistograph drilling at either DBH or at an decay indicator as follows; less then 0.1 of the radius remaining as sound wood; between 0.1 and 0.3 of the radius remaining as sound wood; between 0.3 and 0.5 of the radius remaining as sound wood; more than 0.5 and less than 1.0 of the radius remaining as sound wood; and no decay present or a ratio of 1.0. Each set of data was analyzed among the categories of cities, tree species, and DBH using $\chi^{2}$ analysis with an alpha of 0.05 .

\section{RESULTS}

\section{Sample Summary}

Tables 1 and 2 summarize the sample distribution among the four cities, four tree species categories, and four DBH categories. A total of 1848 trees were evaluated for decay. The random sample of trees was most difficult to obtain in Albany because of its smaller tree population, and for sugar maple because of its relative scarcity compared to the other maple species (Table 1). Small diameter silver maples are also relatively rare because most cities are no longer planting this species.

Table 1. Distribution of samples ( $n$ ) in species and DBH by city.

\begin{tabular}{llllll}
\hline & Total & Albany & Buffalo & Rochester & Syracuse \\
\hline Total & 1848 & 434 & 464 & 476 & 474 \\
Norway Maple & 474 & 119 & 115 & 120 & 120 \\
Silver Maple & 472 & 113 & 119 & 119 & 121 \\
Sugar Maple & 433 & 86 & 112 & 120 & 115 \\
Other Species & 469 & 116 & 118 & 117 & 118 \\
& & & & & \\
30.5-45.7cm DBH & 363 & 90 & 85 & 99 & 89 \\
$45.7-61 \mathrm{~cm} \mathrm{DBH}$ & 509 & 134 & 121 & 138 & 116 \\
61-76.2cm DBH & 557 & 131 & 128 & 154 & 144 \\
$76.2 \mathrm{~cm} \mathrm{DBH}$ & 419 & 79 & 130 & 85 & 125 \\
\hline
\end{tabular}

Table 2. Distribution of samples ( $n$ ) in DBH by species.

\begin{tabular}{llllll}
\hline & Total & $\begin{array}{l}\text { Norway } \\
\text { Maple }\end{array}$ & $\begin{array}{l}\text { Silver } \\
\text { Maple }\end{array}$ & $\begin{array}{l}\text { Sugar } \\
\text { Maple }\end{array}$ & $\begin{array}{l}\text { Other } \\
\text { Species }\end{array}$ \\
\hline Total & 1848 & 474 & 472 & 433 & 469 \\
$30.5-45.7 \mathrm{~cm} \mathrm{DBH}$ & 363 & 100 & 82 & 88 & 93 \\
$45.7-61 \mathrm{~cm} \mathrm{DBH}$ & 509 & 137 & 106 & 124 & 142 \\
$61-76.2 \mathrm{~cm} \mathrm{DBH}$ & 557 & 155 & 138 & 137 & 127 \\
$76.2 \mathrm{~cm} \mathrm{DBH}$ & 419 & 82 & 146 & 84 & 107 \\
\hline
\end{tabular}

\section{Decay Incidence}

Figures 1-3 summarize the incidence of decay by city, species, and DBH. Overall, 1078 of the 1848 samples (58.3\%) had some decay. The greatest amount of decay in sampled trees was in Syracuse at $61.2 \%$, while the least was found in Buffalo at $56 \%$, although $\chi^{2}$ analysis showed no difference amongst cities (Figure $1)$. The highest incidence of decay by species class was in sugar maple at 63\%, and the least was in silver maple 53.6\% and incidence was significantly different amongst species (Figure 2). For DBH classes, the largest number of decayed trees was found in the $61-76.2 \mathrm{~cm}(24-30$ in) DBH class at $63.2 \%$, and the least in the $30.5-45.7 \mathrm{~cm}(12-18$ in) DBH class at $53.2 \%$ (Figure 3 ).

\section{Decay Severity}

Figures 4-7 summarize decay severity by city, species, and DBH. Overall, 60 of the 1848 samples had severe decay (3.2\%) where more than two-thirds of the radius was decayed. Severe decay was determined when the calculated ratio of sound wood distance to radius was equal to or less than 0.30 (over two-thirds of radius decayed) based on an average from the Resistograph results at either $\mathrm{DBH}$ or at an indicator.

The greatest amount of severe decay of sampled trees was in Buffalo at $4.5 \%$, and the least was found in Rochester at $1.5 \%$, but severity was not significantly different amongst cities (Figure 5). Silver maple had the greatest amount of severe decay with 5.3\%, while the least was sugar maple at $1.8 \%$ and species was signifi- 


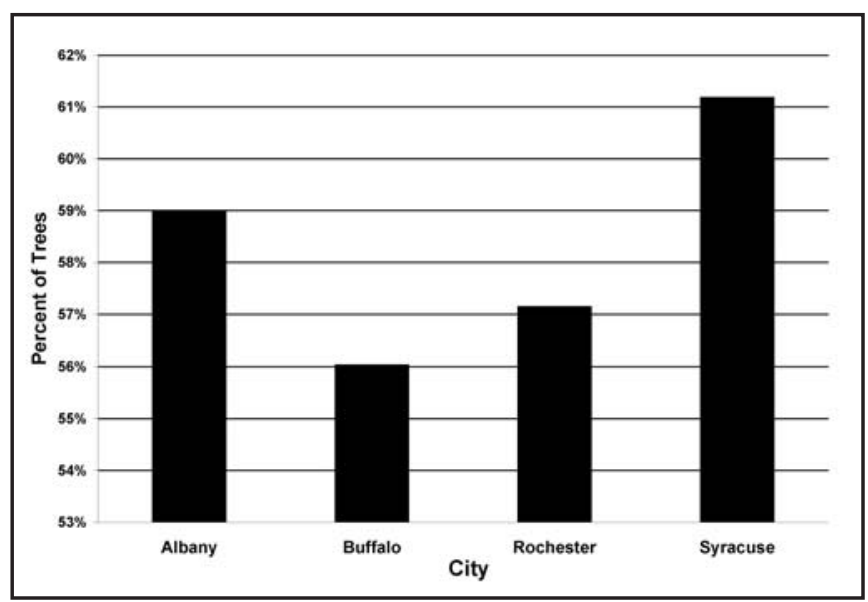

Figure 1. Decay incidence in Albany, Buffalo, Rochester and Syracuse (positive incidence if ratio of sound wood distance to radius was less than 1.00 at either DBH or indicator test sites drilled with a Resistograph F400). $\chi^{2}$ analysis showed no difference amongst the cities $\left(p=0.05 \chi^{2}\right.$ test statistic $=2.9$ for 3 degrees of freedom with a critical value of 7.8 ).

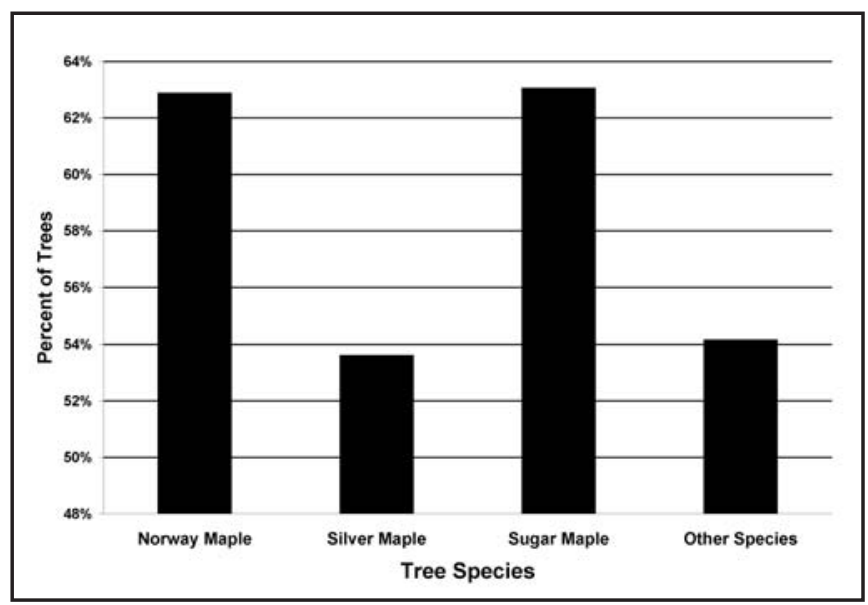

Figure 2. Decay incidence by species (positive incidence if ratio of sound wood distance to radius was less than 1.00 at either DBH or indicator test sites drilled with a Resistograph F400). $\chi^{2}$ analysis showed a significant difference amongst the species $\left(p=0.05 \chi^{2}\right.$ test statistic $=\mathbf{1 5 . 6}$ for 3 degrees of freedom with a critical value of 7.8 ).

cantly different for severe decay (Figure 6). For DBH classes, the largest amount of decayed trees were found in the greater than $76.2 \mathrm{~cm} \mathrm{DBH}$ class at $7.2 \%$, and the least in the $30.5-45.7 \mathrm{~cm}$ (1218 in) $\mathrm{DBH}$ class at $0.3 \%$ and DBH was significant (Figure 7).

\section{DISCUSSION}

\section{Incidence of Decay}

Decay incidence in the trees sampled was substantially higher than reported by Tate (1984; Tate 1986) as over $58 \%$ of the trees had at least some decay in this study. Tate (1986) reported decay incidence of $13 \%$ for street trees in New Jersey. However, that study used an increment borer of unspecified length and only tested trees in a single location. In this study, decay beyond the length of the Resistograph drill bit would have gone

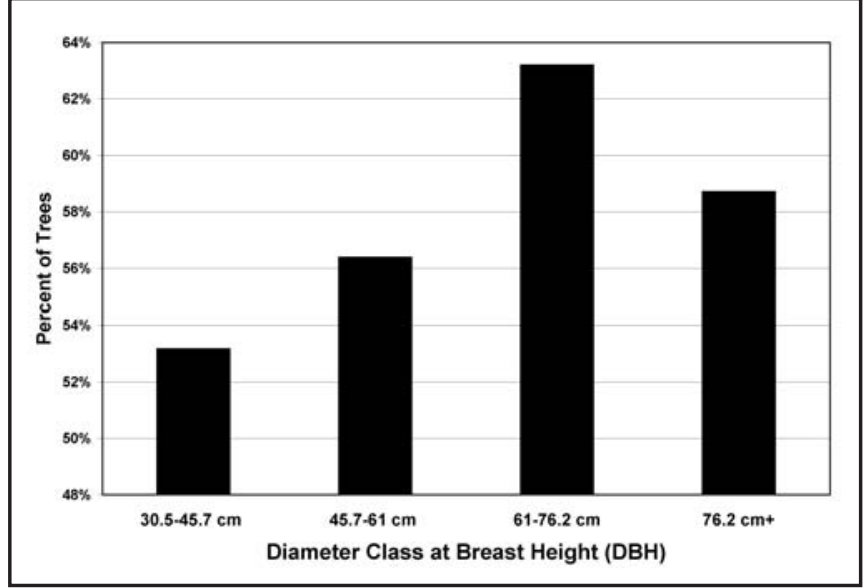

Figure 3. Decay incidence by DBH classes (positive incidence if ratio of sound wood distance to radius was less than 1.00 at either DBH or indicator test sites drilled with a Resistograph F400). $\chi^{2}$ analysis showed a significant difference amongst the diameter classes $\left(p=0.05 \chi^{2}\right.$ test statistic $=10.2$ for 3 degrees of freedom with a critical value of 7.8 ).

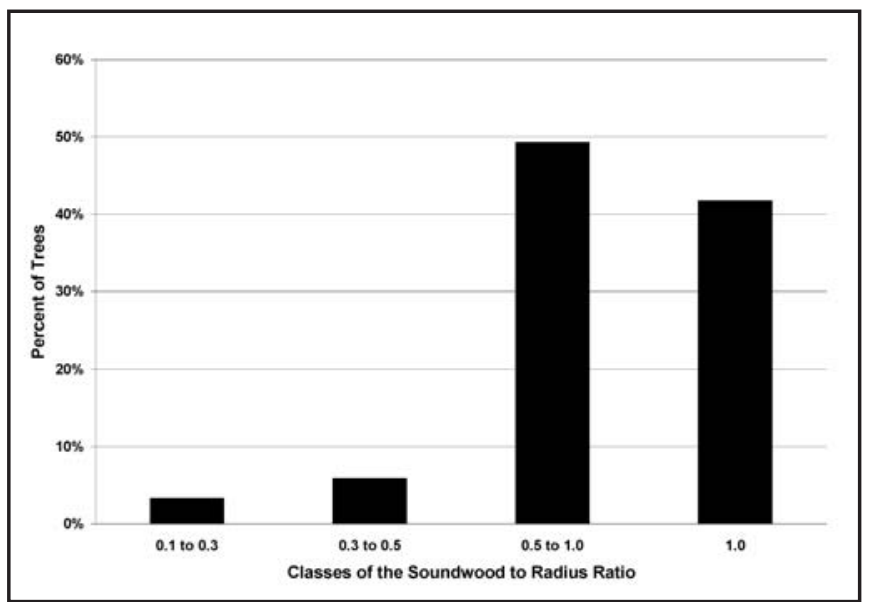

Figure 4. Distribution of decay severity based on the ratio of sound wood distance to radius for all the trees sampled in the four cities combined.

undetected in trees that were in the largest diameter classes or greater than $76.2 \mathrm{~cm} \mathrm{DBH}$. Therefore, decay incidence may be higher than what is reported in this study and may account for the lower incidence in the largest diameter trees compared to the trees in the 61-76.2 cm (24-30 in) DBH class (Figure 3). However, decay beyond $38 \mathrm{~cm}$ (15 in) would not have a significant effect on the stability of the trunk (Kane et al. 2001).

Decay incidence in silver maple was lower than other species, although this tree is well known to be prone to decay (Matheny and Clark 1994). This result may be due to the management activities of the cities forestry programs as silver maple is often targeted for removal because of its decay and defect susceptibility.

Interestingly, decay was present in over $50 \%$ of the trees in the smallest diameter class. This result suggests that decay may become established early in the life cycle of a planted street tree. However, our results showed that decay in smaller size class trees was seldom severe (Figure 7). The origin of the decay (type of wound) in these smaller diameter 


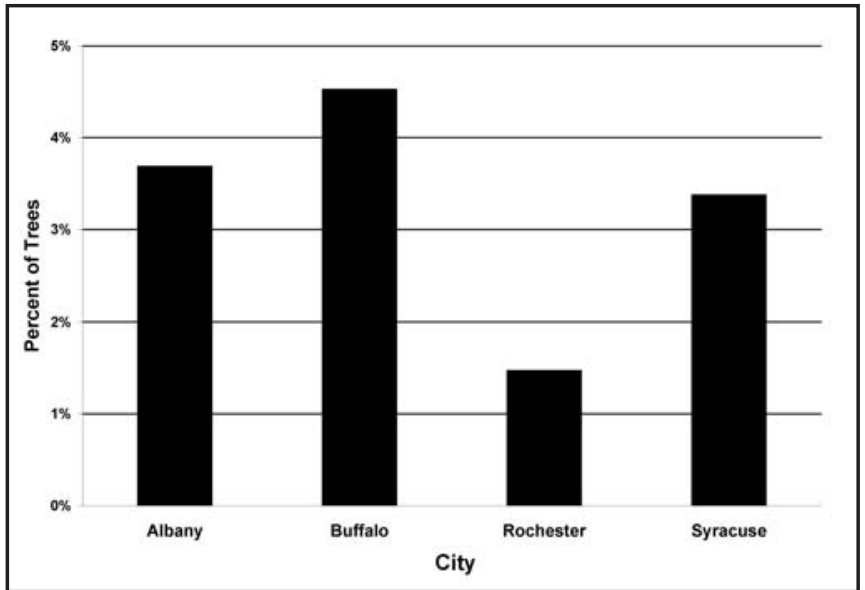

Figure 5. Incidence of severe decay in Albany, Buffalo, Rochester and Syracuse (positive incidence if ratio of sound wood distance to radius was less than or equal to 0.30 at either DBH or indicator). $\chi^{2}$ analysis showed no significant difference amongst the cities $\left(p=0.05 \chi^{2}\right.$ test statistic $=7.5$ for 3 degrees of freedom with a critical value of 7.8).

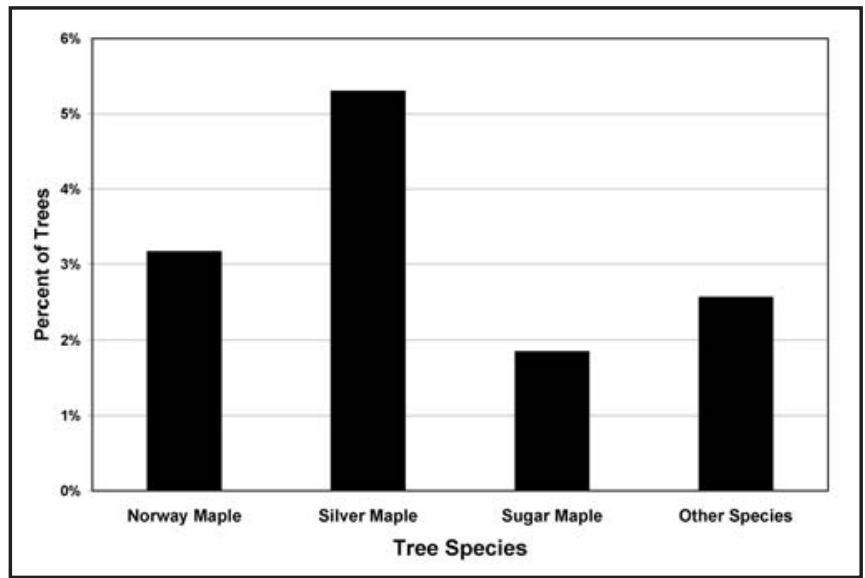

Figure 6. Incidence of severe decay by species (positive incidence if ratio of sound wood distance to radius was less than or equal to 0.30 at either DBH or indicator). $\chi^{2}$ analysis showed a significant difference amongst the tree species $\left(p=0.05 \chi^{2}\right.$ test statistic $=9.7$ for 3 degrees of freedom with a critical value of 7.8).

trees would be worth investigation as it may offer management practices to reduce decay incidence in urban street trees.

\section{Severity of Decay}

Severely decayed street trees, which are most likely to pose an immediate hazard to property and life, comprised 3\% of the sample trees (Figure 4). Data from the study has been provided to each city to allow them to make further inspection and to determine if pruning or removal are necessary. Silver maple had the highest incidence of severely decayed trees. This result is in line with what is known about the reduced ability of silver maple to compartmentalize decay (Hepting 1971). It also suggests that these cities may not be identifying the most decayed silver maples trees for removal given that decay incidence for silver maple was the lowest.

Sugar maple and the random selection of other species present in the four cities had the lowest incidence of severely decayed trees. Sugar maple compartmentalizes decay well (Smith et al.

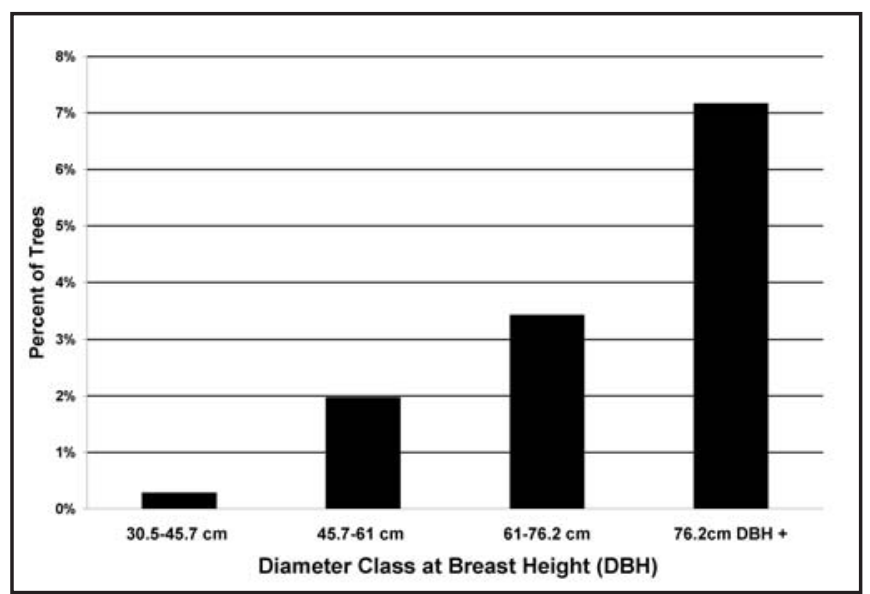

Figure 7. Severe decay incidence by DBH class (positive incidence if ratio of sound wood distance to radius was less than or equal to 0.30 at either DBH or indicator). $\chi^{2}$ analysis showed a significant difference amongst the diameter classes $\left(p=0.05 \chi^{2}\right.$ test statistic $=\mathbf{3 3 . 3}$ for 3 degrees of freedom with a critical value of 7.8).

2001); this result also suggests that a collection of other species with varying decay compartmentalization abilities may be a buffer to the development of severely decayed trees in a population.

These results show that the incidence of severely decayed trees was relatively low in these four cities. Importantly, these data do not represent failure rates, although trees with greater than twothirds their radius decayed are believed to be at increased risk for failure (Mattheck et al. 1993). However, the ability to predict failure based on decay severity alone has been questioned recently (Brudi and van Wassenaer 2002; Bond 2006; Gruber 2007).

\section{Management Implications}

Without street tree management intervention, the proportion of severely decayed trees would be expected to increase as trees mature. The total population of trees greater than $30.5 \mathrm{~cm}$ in the four cities is approximately 67,000. Despite the low incidence of severely decayed trees, there may be over 2,000 seriously decayed trees on the streets in these cities. The location of trees with extensive decay along streets is important because of the higher target occupancy attributed to trees in street locations (Ellison 2005). However, not all trees with decay require removal as strength loss in tree trunks due to decay is low unless decay is severe (Kane et al. 2001). Other factors such as tree exposure, height, and wood strength also affect the risk of failure (Brudi and van Wassenaer 2002). Based on the frequency and severity of decay found in this study, management practices that continue to identify and remove severely decayed trees is important in these and other cities. The implications of these results also need to be addressed as communities and researchers attempt to quantify the environmental and societal benefits of urban trees. Based on these results, estimates of carbon storage by urban trees may need to be adjusted for decay, because wood decay fungi release carbon dioxide (a prominent greenhouse gas implicated in global climate change) as they enzimatically digest the wood of living trees. More study is needed to determine the volume of wood decayed in urban trees and the impact of decay on carbon storage. The high incidence of decay documented in this study of street trees indicate that the research 
published on carbon storage in urban trees (Nowak and Crane 2002; Nowak et al. 2002) may need to be adjusted for decay losses if this degree of decay is found throughout the urban forest.

Acknowledgments. The authors acknowledge the generous support of the Hyland Johns Tree Fund and the New York State Department of Conservation which provided monetary support for this research. We also acknowledge Oliver Hein of IML, Inc. for Resistograph assistance.

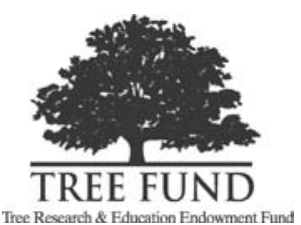

\section{LITERATURE CITED}

Bethge, K., C. Mattheck, and E. Hunger. 1996. Equipment for the detection and evaluation of incipient decay in trees. Arboricultural Journal 20:13-37.

Bond, J. 2006. Foundations of tree risk analysis: Use of $t / R$ to evaluate trunk failure potential. Arborist News 31-34.

Brashaw, B.K., R.J. Vatalaro, J.P. Wacker, and R.J. Ross. 2005. Condition assessment of timber bridges. 1. Evaluation of a micro-drilling resistance tool. USDA General Technical Report FPL-GTR-159.

Brudi, E., and P. van Wassenaer. 2002. Trees and statics: Nondestructive failure analysis. In Smiley E. T. and K. Coder (Eds.). Tree Structure and Mechanics Conference Proceedings: How trees stand up and fall down. International Society of Arboriculture, Champaign, IL.

Costello, L.R., and S.L. Quarles. 1999. Detection of wood decay in blue gum and elm: An evaluation of the Resistograph and the portable drill. Journal of Arboriculture 25:311-317.

Ellison, M.J. 2005. Quantified tree risk assessment used in the management of amenity trees. Journal of Arboriculture 31:57-65.

Gilbert, E.A., and E.T. Smiley. 2004. Picus sonic tomography for the quantification of decay in white oak (Quercus alba) and hickory (Carya spp.) Journal of Arboriculture 30:277-281.

Gruber, F. 2007. Die VTA-0,32-estwandstärkenregel, wissenschaftlich unhaltbar und praktisch unbrauchbar. Agrar- und Umweltrecht 1:7-12.

Isik, F., and B. Li. 2003. Rapid assessment of wood density of live trees using the Resistograph for selection in tree improvement programs. Canadian Journal of Forest Research 33:2426-2435.

Hepting, G.H. 1971. 1971. Disease of forest and shade trees of the United States. USDA Forest Service, Agriculture Handbook Number 386. $658 \mathrm{pp}$.

Jaenson, R., N. Bassuk, S. Schwager, and D. Headley. 1992. A statistical method of the accurate and rapid sampling of urban street tree populations. Journal of Arboriculture 18:171-183.

Kane, B., D. Ryan, and D. V. Bloniarz. 2001. Comparing formulae that assess strength loss due to decay. Journal of Arboriculture 27:78-87.

Luley, C. J. 2006. Identifying wood decay and wood decay fungi. Arborist News 15:12-19.

Manion, P.D. 1981a. Norway maple decline. Journal of Arboriculture 7:38-42.

Manion, P.D. 1981b. Tree disease concepts. Prentice-Hall, Englewood Cliffs, NJ. 399 pp.
Matheny N., Clark J. 1994. A photographic guide to the evaluation of hazard trees in urban areas. 2nd edition International Society of Arboriculture. Savoy, IL. 85 pp.

Mattheck, C., and H. Breleor. 1994. Field guide for visual tree assessment (VTA). Arboricultural Journal 18:1-23.

Mattheck, C., K. Bethge, and D. Erb, 1993. Failure criteria for trees. Arboricultural Journal 17:201-209.

Mattheck, C., K. Bethge, and W. Albrecht. 1997. How to read the results of the Resistograph M. Arboricultural Journal 21:331-346.

Nicolotti, G., and P. Miglietta. 1998. Using high-technology instruments to assess defects in trees. Journal of Arboriculture 24: 297-302.

Nowak, D.J., and R. Rowntree. 1990. History and range of Norway maple. Journal of Arboriculture 16:291-296.

Nowak, D.J., J.C. Stevens, S.M. Sisinni and C.J. Luley. 2002. Effects of urban tree management and species selection on atmospheric carbon dioxide. Journal of Arboriculture 28:113-122.

Nowak, D.J. and D.E. Crane. 2002. Carbon storage and sequestration in urban trees in the USA. Environmental Pollution 116:381-389.

Shigo, A.L. 1966. Decay and discoloration following logging wounds on northern hardwoods. USDA Forest Service, Research Paper, NE-47.

Smith, K.T., W.C. Shortle, and K.R. Dudzik. 2001. Patterns of storm injury and tree response. USDA Forest Service, Northeastern Area, NA-TP-02-01.

Sisinni, S.M., W.C. Zipperer, and A.G. Pleninger. 1995. Impacts from a major ice storm: Street tree damage in Rochester, NY. Journal of Arboriculture 21:156-167.

Tate, R.L. 1984. Stem decay in Central Park. Journal of Arboriculture 10:307-308.

Tate, R.L. 1986. Stem decay in street trees in New Jersey and park trees in Central Park, New York. Journal of Arboriculture 12:73-74.

Young, C.W.T. 1984. The external signs of decay in trees. Arboricultural Leaflet 1. 12pp.

Christopher J. Luley (corresponding author)

Vice President

Urban Forestry LLC

6050 Hicks Rd.

Naples, NY 14512, U.S.

chris@urbanforestryllc.com

David J. Nowak

Project Leader

USDA Forest Service, Northern Research Station

5 Moon Library, SUNY-ESF

Syracuse, NY 13210, U.S.

\section{Eric J. Greenfield}

Forester

USDA Forest Service, Northern Research Station

5 Moon Library, SUNY-ESF

Syracuse, NY 13210, U.S. 
Résumé. Une sélection proportionnelle et aléatoire d'érables de Norvège, d'érables argentés, d'érables à sucre et d'autres espèces d'arbres de rues parmi quatre classes de diamètres ont été inventoriés en regard de l'incidence de la carie et de sa sévérité, et ce au sein de quatre villes - Albany, Buffalo, Rochester et Syracuse - dans l'état de New York. La carie était évaluée en perçant des trous à l'aide d'un résistographe dans les arbres échantillonnés et en calculant le ratio de bois sain par rapport au rayon. Au total, 58,3\% des arbres échantillonnés avaient un certain taux de carie et l'incidence en était la plus grande chez les érables à sucre et parmi les arbres de la classe des plus gros diamètres. Quoiqu'il en soit, l'incidence de la carie était élevée $(53,2 \%)$ même chez les arbres de la classe des plus petits diamètres, soient ceux de 30,5 à $45,7 \mathrm{~cm}$. La sévérité de la carie était la plus grande chez l'érable argenté et parmi les arbres de la classe des plus gros diamètres, et ce même si seulement $3,2 \%$ des arbres échantillonnés avaient des caries plus sérieuses. L'étude a démontré que la carie est courante chez les arbres de rues urbains mais quelle est rarement sévère. Elle suggère également que la carie s'installe tôt dans la vie des arbres de rues mais qu'elle est plus sévère chez ceux de gros diamètres qui compartiment de manière moins efficace tel que l'érable argenté. La fréquence et la sévérité de la carie dans les villes étudiées indique qu'elles doivent poursuivre la détection et la gestion des arbres cariés.

Zusammenfassung. Eine proportionale, zufällige Auswahl von Berg-, Silber- und Zuckerahornen als Straßenbäume und andere Baumarten in vier Durchmesserklassen wurden in vier Städten im Bundesstaat New York auf Anzeichen und Ausmaß von Fäulnis untersucht. Die Fäulnis wurde durch eine Resistograph-Bohrung bestimmt und das Verhältnis des gesunden Holzes in Beziehung zum Radius kalkuliert. Insgesamt hatten 58,3 \% der untersuchten Bäume etwas Fäule, wobei die Zuckerahorne und die Bäume in der höchsten Durchmesserklasse die meiste Fäule aufwiesen. Dennoch war das Vorkommen von Fäule auch in kleinen Du- rchmesserklassen (30,5 - 45,7 cm) hoch (53,2 \%). Der Fäulnisbefall war in Silberahornen und in den größten Durchmesserklassen am größten, obwohl nur 3,2 \% der Bäume ernsthafte Fäulnis aufwiesen. Die Studie zeigte, dass Fäulnis in Straßenbäumen gewöhnlich, aber selten schwer ist. Es zeigt auch, dass Fäulnis schon früh in Straßenbäumen auftritt, aber erst in Bäumen mit größerem Durchmesser und Bäumen mit schlechten Abschottungseigenschaften, wie Silberahorn, standsicherheitsgefährdend wird. Die Häufigkeit und Schwere der Fäulnis in den untersuchten Städten zeigt, dass diese Studien fortgeführt werden müssen, um befallene Bäume zu identifizieren und zu pflegen.

Resumen. Se evaluó una selección aleatoria de árboles urbanos Norway, maples y otras especies, entre cuatro clases diamétricas, en las ciudades de Albany, Buffalo, Rochester y Syracuse para conocer la incidencia y severidad de la descomposición. La descomposición fue determinada taladrando muestras de árboles con un Resistógrafo y calculando la relación de madera sana con el radio. En general, 58.3\% de los árboles muestreados tuvo alguna cantidad de descomposición y la incidencia fue más alta en los arces azucareros y en las clases de tamaño más grandes. Sin embargo, la incidencia de la descomposición fue alta (53.2\%) aun en las clases de tamaño más chicas, $30.5-45.7 \mathrm{~cm}$ (12-18 pulg). La severidad de la descomposición fue más alta en el arce plateado y en las clases de tamaño más grandes, aunque solamente $3.2 \%$ de los árboles muestreados tuvo decaimiento severo. El estudio muestra que la descomposición es común en los árboles urbanos pero rara vez es severa. También sugiere que la descomposición se establece en las etapas tempranas de la vida de los árboles pero es más severa en árboles de grandes diámetros y en aquellos que compartimentan la descomposición pobremente tales como los arces plateados. La frecuencia y severidad del decaimiento en las ciudades estudiadas indica que es necesario continuar investigando para identificar y manejar los árboles afectados. 